\title{
EHMTI-0152. Epidemiology of primary headaches among adolescents in republic of Croatia
}

\author{
M Sedlic ${ }^{*}$ D Mahovic \\ From 4th European Headache and Migraine Trust International Congress: EHMTIC 2014 \\ Copenhagen, Denmark. 18-21 September 2014
}

The aim of our research was to perform an epidemiological study of migraine and tension headache among adolescents in Republic of Croatia and to determine whether there are differences in prevalence, socioeconomic status, headache onset, gender distribution, health care utilization and self-medication between these two types of primary headaches.

We have surveyed 1876 students attending 18 secondary schools in 10 cities of Croatia using self-administered questionnaire that was designed to classify respondents into a group of migraine or tension headache according to Lipton criteria for migraine and ICHD-2 criteria for both migraine and tension headache.

Prevalence of migraine was $12,8 \%$ (17\% in women and $8,1 \%$ in men) and prevalence of tension headache was $38,3 \%$ (40,6\% in women and $35,7 \%$ in men). Prevalence of migraine with TTH was $2,9 \%$ (3,1\% in women and $2,7 \%$ in men). There was significant difference in prevalence of migraine $(\mathrm{OR}=2,3)$ and tension headache $(\mathrm{OR}=1,23)$ between female and male students. We have found that migraineurs were more prone to self-medication $(\mathrm{OR}=3,29)$, as to health care utilization $(\mathrm{OR}=8,12)$. Also we have identified smoking as a precipitating factor for migraine.

The prevalence of primary headaches in Croatia is similar to that in other countries of the world, tension headache is the most common primary headache, occurring later than migraine, and both types are more common in females. Smoking is a risk factor for developing migraine. Although migraineurs visit the doctor and take medications more frequently, both headaches are underdiagnosed and undertreated.

No conflict of interest.

Neurology, Clinical Hospital Center Zagreb, Zagreb, Croatia
Published: 18 September 2014

doi:10.1186/1129-2377-15-S1-B20

Cite this article as: Sedlic and Mahovic: EHMTI-0152. Epidemiology of primary headaches among adolescents in republic of Croatia. The Journal of Headache and Pain 2014 15(Suppl 1):B20.
Submit your manuscript to a SpringerOpen ${ }^{\bullet}$ journal and benefit from:

- Convenient online submission

- Rigorous peer review

- Immediate publication on acceptance

- Open access: articles freely available online

- High visibility within the field

- Retaining the copyright to your article

Submit your next manuscript at $\boldsymbol{~ s p r i n g e r o p e n . c o m ~}$ (c) 2014 Sedlic and Mahovic; licensee Springer. This is an Open Access article distributed under the terms of the Creative Commons Attribution License (http://creativecommons.org/licenses/by/2.0), which permits unrestricted use, distribution, and reproduction in any medium, provided the original work is properly cited. 